No. 6(57), 2018, pp. 81-89

https://doi.org/10.12797/Politeja.15.2018.57.05

\author{
Alvydas JOKUBAITIS \\ Vilnius University \\ alvydas.jokubaitis@tspmi.vu.lt
}

\title{
THE OTHER EUROPE: IDENTITY PROBLEMS OF CENTRAL EUROPE
}

ABSTRACT Philosophers in Central Europe are highly dependent on the Western European tradition of philosophy, while politicians in the region tend to use arguments that are often foreign to the ones used in Western Europe. The philosophical tradition of Central Europe is dependent on Western European tradition - it would be impossible to speak about any kind of distinct regional philosophical paradigm. The situation with political self-understanding in the region is very different. The politicians in the region are aware of the various differences between the two cultural and political traditions. Today these differences have become especially clear in various disagreements between politicians from the Visegrád Group and their colleagues in Western Europe. Politicians from Central Europe propose their own understanding of the meaning of Western civilization. This phenomenon can be described as a new political Messianism. The old Messianims of the $19^{\text {th }}$ century today are being replaced by new consciousness of the specific mission of the region. Conservative politicians propose an understanding of the region which is based on cultural differences from Western Europe. Various conceptions about the singular identity of the region that were developed in the ninth decade of the $20^{\text {th }}$ century by Czesław Miłosz, Milan Kundera and György Konràd today are gaining a new political significance.

Key words: Central Europe, philosophy, nation state, regional messianism 


\section{INTRODUCTION}

During the last two centuries the region of Central Europe has been described by many different names. Some people saw this region as forming the Eastern part of Western civilization, others perceived it as the Western part of Eastern Europe. During the interwar period the region was called cordon sanitaire, today many people refer to it as the „New Europe“. The list of geographical names could be extended. However, this is not the aim of the paper. The aim is to understand how the intellectual discussions about the identity of the region have become politicized. Miłosz, Kundera and Konràd created a notion similar to the national romanticisms of the $19^{\text {th }}$ century. Today this new type of romanticism is applied to the entire region and not to individual nations. Questions that a few decades ago were discussed in small circles by intellectuals today have become major issues of foreign policy. To comprehend this development we have to understand the dependence of Central Europe on Western Europe. The intellectual identity of the region is completely dependent on that of the great tradition of Western philosophy. However, politicians in Central Europe have shown that they are capable of defending the political identity of the region. This contemporary discrepancy between the intellectual and political identities is the key to our understanding of the phenomenon of Central Europe. The politicians in the region are completely dependent on the Western European philosophical tradition and this intellectual dependence is being used to promote a new regional identity.

\section{INTELLECTUAL DEPENDENCE}

When Westerners talk about Europe, they often think about Western European states, which they regard as superior to the remaining part of the continent. Many Westerners would even go as far as calling it 'the real Europe'. People tend to see Central Europe as being not nearly as important as the Western European states. These 'two Europes' have to be constantly involved in discussions about their relations. Western Europe resembles a certain Platonic idea of Europe. As Plato said, it is better to look at the shadows of Gods than at the shadows of their images. Central Europe is conceived by the global community merely as a reflection of the image of Western Europe. The tradition of European philosophy has common roots which stretch back to Ancient Greece. However, the philosophical life of Central Europe differs greatly from the philosophical life of Western Europe. This fact cannot be eradicated by the current political and cultural European integration. The intellectuals of Central Europe are influenced by a kind of schizophrenic self-understanding. This psychiatric term should be understood in its original sense - as a split of the soul. This division of cultural self-understanding occurs after the authentic perception of one's own identity has been lost. In Central Europe this happens after the perception of reality is replaced by the transposition of Western ideas.

One could start talking about the intellectual infertility of the philosophers in Central Europe. But this situation cannot be explained by a lack of local talent. The 
philosophical traditions in the region are different from those in the West. Every single generation of philosophers sweeps away all the achievements of the preceding generations. Every new generation of Central European philosophers tends to look for new authorities in the West rather than hold in esteem predecessors from their own countries. Local philosophical tradition is always regarded as something of secondary importance. The philosophers of Central Europe focus first and foremost on their mentors in Western Europe. This leads them to neglect their own local philosophical legacy and traditions.

Philosophical thought in Central Europe tends to be blind to the local political, economic and cultural realities. After the Second World War Central and Western parts of Europe lived under different conditions. The consequences of this situation are manifested in the differences of spiritual and material culture. The social worlds of Central and Western Europe differ in their structure of meanings. However, these differences are not visible on the level of highly abstract philosophical thought. More often than not, philosophers from Central Europe tend focus on Western ideas rather than on their local reality. Within the region of Central Europe there exists a unique relationship between philosophy and reality. Thinkers from this region embrace the ideas coming from the West in a certain ideal space which bears very little resemblance to their cultural environment. Even though idealization seems to be an inevitable element of any philosophical discourse, in Central Europe it tends to become a means of escaping from one's cultural environment. In turn this creates a phenomenon of ideological mystification - the same philosophical ideas are used to describe two different realities. As Karl Marx put it, men and their circumstances appear upside down as in a camera obscura.

In Central Europe the relationship with philosophy is different to the one that exists in the West. In the former philosophers are merely engaged in taking over the Western philosophical ideas and lose sight of the social, cultural and political particularities of the region. Transition from communism means that any direct political coercion imposed on philosophy is a matter of the past. However, this act of political emancipation does not mean that philosophy in Central Europe has entered a new stage of its history when it would no longer be bound by any restrictions. The end of one 'regime of truth' marks the beginning of another. The fall of Soviet Marxism does not mean that philosophy in the region has become free from any forms of domination. Brutal forms of political coercion imposed on philosophy have been replaced by a much milder Western 'regime of truth'. The end of the Marxist philosophical regime did not bring about any miracle of complete liberation of philosophical discourse in Central Europe.

After the political regime has radically changed, the philosophers of Central Europe had to create a new 'theatre of ideas' and rehearse new roles. A new philosophical discourse had to be created. The philosophers who matured in the previous philosophical regime test their old beliefs and views under new conditions of freedom of discussion. Very often these thinkers have radically changed their positions. One of the biggest paradoxes is that almost no philosophers have noticed how completely they have changed 
their philosophical positions. The majority claim that, rather than having subscribed to Marxism, they merely attempted to philosophize within the framework of a politically imposed Marxist discourse. It seems that all philosophers who helped to maintain the old political system by their philosophical works and public statements have mysteriously disappeared. In a way, this reminds one of the psychic mechanisms of forgetfulness described by Sigmund Freud. People tend to forget the thing that would bring about unpleasant memories, the things they would rather not remember.

The end of the Soviet period in Central Europe highlighted the significance of the figure of lecturer of philosophy. His vocation is to transfer philosophical ideas from one environment to another, that is, to repeat within the framework of his awareness and mentality something that has been stated in other countries. This means that the vocation of philosophers forces them to behave in a conformist way. Such a person is overwhelmed either by the ideas he is paid to teach or by the environment in which these ideas are being preached. ${ }^{1}$ In the Middle Ages there existed a distinction between an actor, who created new discourse, and a lector, who provided comments on the established discourses. We have to admit that in Central Europe we know only of philosophical discourse created by lecturers. The opening up of Central Europe to the West and transition to a new philosophical regime was another confirmation of this. The present-day philosophical literature in the region abounds in translations and reproductions of the ideas of contemporary Western thinkers. The whole -post-communist region today is forced to become aware that political liberation from the coercion of totalitarian state does not mean the abolition of all restrictions on discourse.

Many advantages of the new post-communist 'regime of truth' are self-evident. Philosophers have acquired the right to freely publish their works and freely change convictions. Nevertheless, it is quite obvious that in Central Europe philosophers merely take over the most popular Western ideas and translate them into local languages. Central Europe is characterized by a dual nature. People live and act in one cultural environment and yet they tend to seek for ways to justify their activities elsewhere, be it France, Great Britain, Germany or the USA. Thirty years ago Central European philosophers spoke in the words of Marx and Lenin. Today they tend to get their philosophical vocabularies in Paris, London or Berlin. In both cases philosophical dependence is motivated in a similar way. The old social order of Central European life has to be replaced. One type of identity is created in the practical sphere, another in philosophy. Representing the periphery of European civilization and constantly looking for their cultural identity, Central European philosophers tend to perceive Western philosophy as a cultural sign. Serious disagreements with Western Europe are an important aspect of the contemporary political life in Central Europe. In philosophy, humanities and social sciences such disagreements are almost nonexistent.

P. Nowak, Hodowanie troglodytów. Uwagi o szkolnictwie wyższym i kulturze umystowej cztowieka wspótczesnego, Warszawa 2014, p. 163. 


\section{POLITICAL INDEPENDENCE}

The four countries of the Visegrád Group, Poland, Hungary, Czech Republic and Slovakia, form the core of Central Europe. Culturally, countries like Lithuania, Slovenia, Croatia, parts of Ukraine and Belarus can claim to belong to the region. Historically the philosophical tradition in these countries has been dependent on Western philosophical ideas. If we compare the philosophical traditions of Central Europe with those of Russia we can notice that the Russians tend to emphasize their independence from the West. The first original Russian philosopher Vladimir Solovyev began his book The Crisis of Western Philosophy: Against the Positivists with a statement that Western philosophy had reached its crisis. ${ }^{2}$ This manner of speaking is foreign to the philosophers of Central Europe. Before pronouncing any verdict on Solovyov's statement about the crisis of Western philosophy, philosophers in the region would look to their colleagues in the West. A book by Frederick Copleston on the history of Russian philosophy is called Philosophy in Russia. The author might have wanted to emphasize that philosophy in Russia is an imported commodity. In his opinion the Russians have no need for pure philosophy but use it as a means to investigate their political life. The situation in Central Europe is different: philosophers see themselves as belonging to the tradition of Western philosophy.

The situation changes dramatically as we proceed from philosophy to politics. Politicians in Central Europe are more independent than philosophers. While philosophers try to accommodate themselves to Western philosophical discourse politicians are not afraid to enter into serious disagreements with their counterparts from Western Europe. It is hard to find any meaningful disagreement on the philosophical plane between Western and Central Europeans. However, politicians in the region often have their own ideas about the unique place of the region and its mission. Intellectual discussions about the other Europe today have been transformed into discussions about the political mission of Central Europe. Politicians from the region are not afraid to speak on behalf of Western civilization. They do not propose any new political ideas that would be hostile to the Western tradition. These politicians are engaged in attempts to find alternatives within this tradition. The main difference is that in Central Europe conservative positions about the future of Western civilization are put forward by politicians who are in governments. Some politicians in the region argue that Central Europe has been more successful in protecting the heritage of Western civilization which they see as being neglected in Western Europe. This is an attempt to return to Milan Kundera's idea that people in the region managed to protect the ideals of Western culture. ${ }^{3}$

Philosophers in Central Europe do not engage in discussions with their colleagues from the West in the name of any separate region. This kind of discussion today takes

2 C. Copleston, Philosophy in Russia. From Herder to Lenin and Berdyaev, Notre Dame, Indiana 1986, p. 207.

3 M. Kundera, "The Tragedy of Central Europe", The New York Review of Books, vol. 31, no. 7 (1984), pp. 34-38. 
place only on the level of politics. However, even these discussions between politicians are discussions within the same tradition of political thought. Politicians from the states of the Visegrád Group advocate the idea that Central Europe is a unique region. This is an attempt to promote an alternative perspective on the future of the European Union. Western and Central European politicians disagree on what the future of Europe should look like. The idea that Central Europe is unique is inseparable from the belief that this region has a special mission in defending the ideals of Western civilization. This can be described as a politicization of the ideas of Kundera and other intellectuals from the region. ${ }^{4}$

Politicians from Central Europe do not promote any new political ideas. They tend to repeat ideas from the conservative tradition of Western political thought. These politicians are not original thinkers. The majority of important disagreements between Western and Central Europeans can be traced back to a different understanding of the role and value of the nation state. The process of state building in Central Europe began with the formation of national consciousness. Traditions of political thought in Central Europe were shaped by the struggle for cultural survival. This is the reason why political discussions in the region are inseparable from cultural issues. This cultural aspect of political freedom is of little or no interest to those politicians in the Western part of Europe who tend to speak the language of universal principles, i.e. human rights, justice and democracy. To many people in Central Europe this focus on universal principles is too narrow because it is blind to their historical experiences. The nations of the region managed to attain statehood only after a successful struggle for cultural identity. A struggle for national states that lasted for almost two centuries is foreign to the historical experience of Western Europeans. In Central Europe the struggle for independent states is inseparable from the attempts to protect the cultural identity of the nation.

Today many intellectuals from Western Europe have little knowledge about the historical peculiarities of Central Europe. From their very establishment the states in the region have been a peculiar fusion of politics and culture. Kundera is right when he states that the nations of Central Europe preserved memories of Western Europe "in which culture had not yet entirely bowed out." However, he does not speak about one important political circumstance that today is growing in importance. States in the region came into being as part of a struggle for cultural survival. Nations in the region fought for their freedom from the Austro-Hungarian and Russian empires by fighting for their culture. The political formula of the nation state in Central Europe always meant something more than it did in Western Europe. The struggle for cultural independence in Central Europe was the beginning of the struggle for political independence. Before the establishment of political independence the nations of the region had to establish their cultural identity. It is impossible to understand democracies of Central Europe without paying any attention to the phenomenon of nationalism. In their

G. Konrád, “Is the Dream of Central Europe Still Alive?”, Cross Currents, no. 5 (1986), pp. 109-121;

C. Miłosz, "Central European Attitudes", Cross Currents, no 5 (1986), pp. 101-108.

5 M. Kundera, The Tragedy of Central Europe, p. 37. 
struggle for democratic self-government the nations of the region had to participate in a cultural struggle. Only states that had proven their cultural uniqueness had any chance of becoming independent.

Today intellectuals and politicians in Western Europe tend to reject nationalism and have doubts about the value of the nation state. This position is a negation of the political struggles that the nations of Central Europe have fought during the last two centuries. The nations in the region have been a curious blend of nationalist and cosmopolitan principles. National rebirth was not identical to aggressive nationalism but functioned as an important catalyst for cultural modernization. The leaders of national rebirth movements were striving for progress. The social strata that were most active in the formation of nation states had been cut off from the high culture and this is the reason why they thought that it was necessary to assimilate the achievements of the cosmopolitan Western culture. The modernization of states in Central Europe was a process of liberation from narrow nationalism. The leaders of national rebirth movements saw no alternative to the political formula of Western democracy. They attempted to find a compromise between the culture of their particular nation and democracy.

Contemporary political arguments used by politicians from Central Europe are not new. They belong to the tradition of the conservative wing of Western political thought. This is most evident in Poland, where national identity is inseparably interwoven with Catholicism. This union of nationalism and Catholicism cannot be accepted by the French politicians who belong to the secular tradition. One can find similar disagreements between Germany and other Central European nations on the question of the role of the nation state. Today many politicians in Central Europe perceive contemporary ideals of Western Europeans as being liberal or socialist and argue for a return to Kundera's idea of Central Europe as a unique region. Only the emphasis has changed. Kundera's idea of a 'kidnapped West' is being transformed into a discussion about a unique historical mission of the region. An important factor in this transformation is the historical experience of the region. Western and Central Europe share a common philosophical heritage but disagree on political questions, more precisely on questions about the future of the European Union. Central European states are attempting to establish their political existence on the basis of the political formula of the nation state while Western European states want to have a democracy without a nation and profess what Pierre Manent called 'the religion of humanity.' This civil religion is based on the idea that the citizens of the European Union have to be loyal to political principles, namely human rights, constitutionalism, political justice and equality and not to their particular cultures. In the eyes of those who profess this religion the nation state is an obsolete political formula. This position offends the sensibilities of the citizens of Central Europe. It is no coincidence that this problem has become a bone of contentionwithin the European Union.

P. Manent, Seeing Things Politically. Interviews with Bénédicte Delorme - Montini, South Bend, Indiana 2015 , p. 160. 
Central and Western Europe belong to the same philosophical tradition. There are no significant differences that would allow us to speak of two distinct traditions of philosophy. The intellectual unity between the two regions of Europe is so close that philosophers in Central Europe tend to lose sight of their local reality. In the field of politics there is no such unity between the two regions. Politicians in Central Europe are not afraid to emphasize cultural and political differences between the two regions. In political disputes between the two regions Central Europe is perceived as conservative. Western Europe is identified with liberalism and the New Left. These discussions show that in the European Union there exists a new kind of confrontation between the liberals and the conservatives which is based on disagreements between two regions. Philosophers in Central Europe are completely dependent upon their colleagues from Western Europe. Politicians are advocating an alternative position on the future of the European Union.

In the $19^{\text {th }}$ century Poles, Hungarians, Czechs and Slovaks spoke about cultural mission of their own nations. Today we see a rise of political messianism on a regional level. The conservative messianism of the Visegrád Group is based on arguments borrowed from the tradition of Western conservative thought. Politicians in Central Europe propose a new interpretation of Kundera's idea that Western Europeans have forgotten the ideals of Western culture. Contemporary disagreements within the European Union in many aspects are similar to the emergence of German Romanticism in the $19^{\text {th }}$ century when conservative German politicians rejected French cosmopolitan ideas and argued that a particular cultural experience should be the basis for political life. Central Europe shows that conservative Romanticism can function not only on the level of separate nations, but it can become a political force on a regional level as well. The part of Europe that was cut off from the West after the Second World War today is promoting its own conception of Western culture. Politicians in Central Europe are beginning to talk in the name of the West.

People from various Central European countries are aware that they share similar historical experiences. However, this is a paradoxical awareness. The conservatives in this region think that they defend the ideals of Western civilization, which they believe have been forgotten in contemporary Western Europe. This is the reason why the conservatives in Central Europe tend to speak not only about the local issues but about the ideals of Western civilization. Regional messianism becomes a part of a broader struggle for cultural identity. Politicians from Central Europe are often accused of nationalism. However, regional cooperation clearly shows that this is not the case. The four states of the Visegrád Group agree on universal principles. The aggressive nationalism of the past seems to be left behind. Today these countries are doing more than just forming a political alliance. They have begun an important dialogue about their shared cultural similarities. The nature of these similarities is open to many interpretations. A liberal interpretation of the identity of the region is as well-grounded as the conservative one ${ }^{7}$. Today Central Europe is seen as the fortress of conservatism. Politicians in Central Europe are trying to protect their identity by using arguments from

W. Sadurski, Liberat po przejściach. Publicystyka i eseje 2003-2006, Poznań 2007, p. 125-131. 
the conservative tradition. The idea of Central Europe can have many different political meanings. Today people in the region tend to see this idea as a conservative force.

The uniqueness of Central Europe does not mean that the region is independent from the West. The political thought in the region is a part of the great tradition of Western philosophical thought. Dependence at the level of politics is harder to notice because of the partisan nature of politics and the multitude ofquarreling parties. The conservatives in Central Europe have not put forward any new political ideas, but have been using arguments from the tradition of Western political thought. Today the conservative identity of the region is taking shape among various disagreements with the Western European states. Central Europeans are aware of their cultural backwardness. However, this does not stop them from seeing themselves as belonging to Western civilization. Philosophers in the region do not pay much attention to this cultural backwardness and use the same philosophical concepts as their colleagues in Western Europe. Politicians in Central Europe are dependent on the Western tradition of political thought, too. They depend on the conservative tradition. Even if it were not accurate to say that Central Europe is conservative, one could not help but notice a certain dominance of the conservative tradition in the region. Beside Western Europe there is another Europe that speaks the same philosophical language but wants to find a political form that would fit its historical experience.

\section{BIBLIOGRAPHY}

Copleston C., Philosophy in Russia. From Herder to Lenin and Berdyaev, Notre Dame, Indiana 1986.

Kundera M., "The Tragedy of Central Europe", The New York Review of Books, vol. 31, no. 7 (1984).

Konrád G., "Is the Dream of Central Europe Still Alive?”, Cross Currents, no. 5 (1986).

Miłosz C., "Central European Attitudes", Cross Currents, no 5 (1986), https://doi.org/ 10.17223/18572685/41/9.

Manent P., Seeing Things Politically. Interviews with Bénédicte Delorme - Montini, South Bend, Indiana 2015.

Nowak P., Hodowanie troglodytów. Uwagi o szkolnictwie wyższym i kulturze umystowej cztowieka wspótczesnego, Warszawa 2014.

Sadurski W., Liberat po przejściach. Publicystyka i eseje 2003-2006, Poznań 2007.

Prof. Alvydas JOKUBAITIS, Ph.D. - Institute of International Relations and Political Science, Vilnius University, Lithuania. Published books: Postmodernizmas ir konservatizmas (1997), Liberalizmo tapatumo problemos (2003), Trys politikos aspektai: praktika, teorija, menas (2005), Politika be vertybiu (2008), Vertybiu tironija ir politika (2012), Lietuva kaip problema, co-author R. Lopata (2014), Filosofas kaltina mokslininkus (2016), Liberalizmas kaip pilietine religija (2017), Politinis idiotas (2019). 